\title{
The socio-symbolic function of language
}

\author{
ERNEST W. B. HESS-LÜTTICH
}

Abstract

The article starts from the premise known since antiquity that speech indicates something of the speaker. Language as action is regarded not only as a medium to convey lexical or semantic information but also of social meaning. This raises the question: How can we get access to the social meaning of linguistic structures? This is the main question dealt with throughout the paper, which sets out with carefully defining the notion of symbolic meaning on the grounds of social semiotics. It then develops the sociological concept of group (or community) as a cultural sub-system of society, in order to understand better the relationship between language variation as options of linguistic choice and 'sociolect' as a group specific linguistic variety. Within this conceptual framework, the contours of a socio-grammar are outlined, which describes the socio-symbolic functions of phonetic, prosodic, morphological, lexical, syntactical, textual, and pragmatic elements of linguistic structure. The perspective then broadens to the level of discourse on which the relationship of language and prestige or language and power is dealt with, notabene with a side view on Pierre Bourdieu's notion of the symbolic order of significant difference (in his opus magnum La distinction).

Keywords: socio-semiotics; socio-symbolic function; discourse and prestige; language and power; group languages; communication in subcultures.

\section{Sign - symbol - symptom}

The classic premise of the speaker's social exposure through language is derived from the assumption held since classical antiquity that language provides the hearer with information about the current speaker. This 
notion was also emphasized by Ben Jonson, going back to Erasmus of Rotterdam, in maintaining that 'Language must shewes a man: speake that I may see thee.' Because language is an activity performed by social subjects, it has always been regarded not only as a medium for information but also as a social symbol. The expression symbol is a key concept of multiple disciplines. In the present context it is semiotically specified in two respects, first (1) as a sign after the antique formula aliquid pro aliquo and second, more specifically, (2) as a conventional, arbitrary sign as discussed by Peirce (Nöth 2000: 178-180).

However, 'How can we get access to the social meaning of linguistic structures?' (Dittmar 1983a: 226). What exactly is the 'social meaning' of certain expressions of different linguistic levels of description? Language obtains 'social meaning' through variability: the speaker has a choice. He makes a selection from 'a set of alternative ways of "saying the same thing"' (Labov 1972: 94; Dittmar 1983a: 237). For this, it requires sociolinguistic knowledge 'to define precisely the nature of the linguistic features that are the basis of these judgements of social identity' (Crystal 1987: 38). The speaker's knowledge about the world and about the signs that transmit this information allows him both to communicate to others and to understand what is conveyed to him through a set of familiar signs. The expression of signs is simultaneously, and very literally, an expression of the self: the speaker conveys to others his identity in terms of a 'person' or a 'social subject.' He is not simply a 'sender' of a message and not simply a performer of actions producing utterances. Though he can do this more or less consciously and willingly and more or less clearly, in communication, it is not possible for him not to also convey information about himself (even a catatonic person with his unwillingness to communicate signals the 'social meaning' of a pathological unsociability).

The issue, however, is not only about what a speaker conveys or signals beyond language itself. It is not only about signalling his professional role by wearing a uniform, for example. Nor is it about conveying the underlying message by emphasizing an ironic utterance with the appropriate mimic and prosodic features, by confusing his conversational partner with a discrepancy between the words uttered and the accompanying mimic and prosodic features, or by underlining his status in front of others with certain symbols. It is primarily about the dual characteristic of a sign acknowledged since classical antiquity, which is simultaneously a symbol for a signified third (the referent) and a symptom for personal and social features of the producer. The symptomatic function of a linguistic sign allows its receiver not only to interpret in a symbolicfunctional way what it signifies (objects and facts), but also to make infer- 
ences about what it expresses. This connection has become commonplace since Karl Bühler (1982 [1934]) and is a means of 'membership categorization' with a socially stabilizing and reassuring function without which everyday communication would become awkward and problematic (cf. Hess-Lüttich 1984; Hanke 2000).

\section{Language and the group}

Close examination of a social system from a purely structural or functional point of view suggests that the individual's position in society and his role(s) within are not at all rigid. Status, position, and role are all categories that are inferred through a process of orientation to, cognition and interpretation of, social features derived from of a person's actions. Apart from all systems of status and roles, the individual is situated within social groups, within which his identity is developed and formed. 'Traditional' sociolinguistics was mainly concerned with the attempt to investigate the significance of social classes and roles within the structural and functional dimensions of social systems (e.g., linguistic strata or linguistic codes according to social class in the sense of Basil Bernstein; cf. Hartig 1985: Sprachschichten, rollenspezifische Codes). In this respect, the question of social significance of linguistic signs leads to a focus on the cultural dimension of the group as 'the normal case of socialization' of the individual (Claessens 1995 [1965]: 70, 1977; Fisch 1987).

The process of social standardization allows certain predictions of actions due to conventionalization of rules for social behavior and thus also a condition for cooperative social interaction. The process of differentiation can be seen as diametrically opposed to this. Indeed, the instrumental and affective demarcation of groups based on individual features of their group members leads both to a homogenization and a relativization of expectations, needs, and interests. The balance of tension, the Spannungsbalance (Elias 1977: 2.435), between stability and creativity and between innovation and functionality determines the potential of action and performance of a group.

In terms of differentiation of internal group structures, similar observations can be made concerning larger entities and ultimately also society as a whole. Thus, one can distinguish partial cultures within the overall culture of a society (especially within pluralistic societies), which differ from each other in terms of a corpus of features such as increased groupinternal solidarity and cohesion. Their relation to the overall culture does not necessarily have to be described in terms of their divergence from it, which in social sciences is associated with the term 'sub-culture' 
(Bernsdorf 1972). Rather than measuring the grade of divergence from the 'actual' culture, one can define sub-cultures in terms of their respectively divided rules and maxims, their norms and values, the social features of their members, and the objectives of these group members.

No one speaks the same way all the time, and people constantly exploit the nuances of languages they speak for a wide variety of purposes ... language will be seen to exhibit considerable internal Variation, and single-style Speakers will not be found ... The Variation you are permitted has limits; ... those limits can be described with considerable accuracy ... they apparently apply to groups of Speakers, not just to individuals. That is, there are group norms so far as Variation is concerned. (Wardhaugh 1986: 5)

Group-specific language varieties are the focus of interest of various investigations concerned with the social-symbolic function of language. Its group-specific characteristics or 'insignia' or indices, however, are not objectively defined linguistic forms, but rather products of interaction and interpretation involving the speakers' evaluations of themselves and others as group members and of the speakers' assessment of linguistic features as social indicators of their membership. The social and linguistic differences do not as such obtain relevance in an action-oriented respect, but they do so insofar as they become semiotic manifestations and results of critical evaluation. The position of a social subject within a group of a hierarchical order is defined over the consciousness of its distinction to the positions of other social subjects. In consequence, language variation researchers such as Labov were among the first to maintain that "Speech communities may be defined more precisely by agreement in subjective judgements rather than by agreement in speech behavior" (Labov 1971: 209).

Such consequences have become very important for the methodology of empiric sociolect research. In Germany, for example, tests on language evaluation and speaker assessment conducted in empiric studies on dialectal and sociolectal signals of stigma (Steinig 1976; Jakob 1992) or on the use of dialects in rural communities (Hufschmidt et al. 1983) were systematically integrated into methodical appliance (cf. Giles et al. 1987a, 1987b). Such procedures enable access to the collective knowledge of the test candidates concerning speech variation and stereotype assessments (or prejudices) on variations on a basis of only a small number of features.

These features can be symptomatic indications for stigma- or prestigevariations, for speech strata or local speech variations and for the speaker's origin and educational grade. But they can also be part of the education of groups defining themselves by their use of language (profes- 
sional language, jargon, scientific language) inasmuch as one does not wish to classify them as functional variations. In a broader sense, sociolectal features can be observed 'wherever a group defined by social features is also marked by its symbolic use of a characteristic language variety, i.e., specific lexico-grammatical and intonational patterns' (Löffler 1994: 126, my translation). In a more specific approach, Löffler affords the label 'primary sociolects' only to those speech variations that do not include variations influenced by profession or special field (see Möhn 1980; Hess-Lüttich 1987) and which he classifies into temporal and habitual sociolects (Hess-Lüttich 1987: 129).

Transitory sociolects primarily involve the so-called 'age-group languages,' i.e., the special forms of language used by children and youth (Oksaar 1977; Romaine 1984; Henne 1986; Androutsopoulos 1998; Neuland 2002) or by pupils and students (Küpper and Küpper 1972; Jäger et al. 1978; Weber 1980; Henne and Objartel 1984; Bredehöft and Singermann 1989). Biological categories such as age and gender (language of women, see below), being objects of sociologic interpretation, are in a more narrow view (Hess-Lüttich 1987: 59) only used for the definition of sociolects, because they induce cohesion of sub-cultural groups such as youth groups, adolescent gangs (Hess-Lüttich 1984, ch. 10), feminist and homosexual groups, etc. (Trömel-Plötz 1982; Pusch 1990; Chesebro 1981; Leap 1996; Jacobs 1996; Hall 1997). The language of soldiers (Küpper 1978), inmates (cf. Möhn 1980) or foreigners (interim languages; 'PidginDeutsch' cf. Dittmar and Klein 1975) can, cum grano salis, be included in the area of transitory sociolects (inasmuch as they cannot be counted as habitual sociolects, see below).

Temporal sociolects are special forms of language use in areas such as sport, hobbies, and leisure groups, which occasionally display very specific jargons. Examples for these are language in sport (Schneider 1974; Ris 1995), i.e., among footballers, golfers, and riders. Habitual sociolects are gender-specific ways of speaking, or sexolects (Andresen et al. 1978; Smith 1985; Klann-Delius 1987; Samel 1995; Tannen 1997), as well as the 'classic' (sometimes historic) special variations: the so-called Rotwelsch of the thieves, beggars, etc. (Puchner 1976), the Yiddish language of the merchant Jews, the Jenic language of the travelling people, the gypsy language of the Sinti and Roma. These in turn influenced the languages of the students' duelling societies, the travelling tradesmen, the prostitutes and the urban peripheral groups. Some of their forms have since found entry into everyday and standard language.

The adoption of special language vocabulary into colloquial language simultaneously signals the constant change that sub-cultural jargon is subjected to if it means to retain its character as a 'group-label,' or 
Gruppenabzeichen (Bausinger 1984: 119). The influence of language norms on group-cohesion is exemplified in sects or politically extreme sub-cultures, even though their language has up to this point not yet been systematically analyzed (Cölfen 1999). Such investigations are extremely difficult, because the groups are difficult to gain access to, for 'it is precisely the character of a closed group which in the end allows only a group member insight into its internal communication processes' (Möhn 1980: 388, my translation). In connection with such groups, one is indeed forced to rely on insider information, which sometimes consists of interview protocols (rockers; Knastalphabet) or on-scene interviews as conducted by Hubert Fichte (1972) in the prostitute scene of Hamburg. Further, there are autobiographical accounts, such as by Christiane F. from the Berlin drug scene, or literary-documentary productions in literature and in television broadcasts that find their way into the public. This area yet remains fairly unexplored by empiric research in a most heterogenic field apart from the vast progress of research of structures and processes in 'institutional communication' and 'intercultural communication.'

\section{Socio-grammar}

The question about the social-symbolic function of language opens up a huge variety of research perspectives for language description. Independent studies on the various possibilities of social markedness of linguistic (and extra-linguistic) signs are compelled to supply the foundation for a kind of 'socio-grammar.' Löffler (1994: 199) claims the need for such a construction as an addition to literature-oriented standard grammar and the (still to be produced) standard grammar of spoken language. Current dialect grammars could be a model for a description of sub-systems in the German language. However, a socio-semiotic perspective carries us beyond the field of a single language and could provide a basis for the development of variety grammars adequate to the description of language in its situational and social application (cf. Klein 1974; Klein and Dittmar 1979; Berruto 1987; Klein 1987). British Contextualism, for example, has (out of scientific-theoretical and historic reasons) made a considerable advance in the development of this perspective of language as an organizational form of social experience (Halliday 1978; Hodge and Kress 1991).

There are propositions for a socio-semiotic basis of linguistic description of language variation in the overlapping sections of the scientific fields of language, social-, text-, media- and communication studies (e.g., Hess-Lüttich 1981). They are able to create a scientifically compatible re- 
lation between sociologic-communicative conditions of dialogic actions, as are manifested in the structure of communicative settings (be this in everyday conversation, theoretical discourse or literary dialogue) with text-semiotic conditions of communicative negotiation. The characteristics of the latter negotiation in everyday and aesthetic semiotic processes are specified and analyzed in terms of their media theoretic and textlinguistic aspects. This 'dialogue-linguistic' model obtained from the textual comparison of social and semiotic conditions of communication offers a sufficiently theoretical frame for the examination of regular variants with social, group-oriented and interactional markers on all levels of linguistic description including non-verbal and paraverbal features.

Signs involving mimic, gestural, proxemic, prosodic, vocal-tonemic, chronemic or stronemic features must be included in a non-reductional 'socio-grammar,' because they can attain a prominently social-symbolic meaning in both directly and technically transmitted forms of communication (as well as in 'literary notation': Hess-Lüttich 1985). These signs can be applied for the 'definition' of certain 'communicative settings' as being asymmetric, for the assessment of the communicative partner on the grounds of paraverbal manifestations of his emotional state, for the interpretation of intermediary relations in discrepancies between verbal and non-verbal messages and for the indication of individual, social, ethnical and gender-connected identity of the communicative partner. A 'socio-grammar' must further be able to provide a basis for reflection on conflict potential that can arise from the violation of rules for nonverbal and paraverbal dialogue handling or from the unawareness of inter-ethnic differences in nonverbal and paraverbal communication (Wolfgang 1984; Hess-Lüttich 1982, 1992; Scherer and Giles 1979; Bergmann 1987; Wallbott 1987).

The socio-symbolic importance of these not strictly grammatical, but more language-oriented markers has presently been acknowledged in connection with studies on code-switching (Poplack and Sankoff 1987) and also in the area of language teaching (Hess-Lüttich 1986). There have also been more detailed insights in terms of the systemic integration of pragmatic and textual levels. The social-symbolic relevance for the definition and classification, i.e., of categorisation of texts, conversational types, linguistic styles, and registers were originally not accounted for in traditional grammars (exceptions: Götze and Hess-Lüttich 2002; cf. Adamzik 2000; Krause 2000). Further, there was no sufficient investigation of the socio-semiotic meaning of xenisms on all levels of linguistic description, i.e., of pragmatic xenisms (i.e., in studies of linguistic politeness: Watts et al. 1992; Lüger 2001) and of idiomatic, lexical, syntactical, morphological, and phonological imports of foreign languages (Ehlich 1986). 
Empiric analyses, such as the study on 'social sensitivity to style' in specific groups of speakers (Sornig 1981) supply groundwork for the development of a 'socio-semantics.' Individual variation in the structuring of semantic fields within a certain language further necessitates a 'contrastive socio-semantics' (Oksaar 1988: 25) for the description of the differences in linguistic processes of truth perception and the organisation of knowledge. As a result of such differences, there is a discrepancy in opinion of what is the expressive aim of certain linguistic terms, depending on the language-specific properties of the lexical repertoire and also on the semantic inventory. This problem is not only a concern of translation studies, but also of the investigation of semantically induced communicational conflict among speakers of the same language (Richter and Weidmann 1975).

Such a theory of socio-semantics would be able to pick up the tradition of socio-lexical differentiation of lexical variants in dictionaries. From a research-practical point of view, 'socio-lexis' is currently the most highly developed starting point for the analysis of lexicons that are groupspecific or typical to a certain group. Until now, sociolects were predominantly described as identifiable on a primary lexical basis. Following Löffler's (1994: 201-202) proposition, socio-lexis could also be linked to the analysis and inventory of socially marked phrases and lexical connections ('social phraseology'), as well as to the group-specific motives and allocation functions of names ('socio-onomastics') (Burger et al. 1982; Walther 1972; Ris 1977; Shin 1980).

Further features worth mentioning are the more subtle possibilities of distinction in the social and situational use of modal particles, as well as the possibilities to transfer deictic expressions for topological relations to social orders. Deictic expressions such as 'here,' 'there,' 'to go,' 'to come,' etc., have a routinely updated social meaning in phrases like 'the left wing,' 'the right wing,' 'the (new) center,' 'those up there,' 'us down here,' etc. (Nöth 1994). Foreigners are often accustomed to different topological allocations and have a tendency for an over-generalizing use of certain prepositional phrases referring to topological relations involving social meaning, such as 'he is in to that,' 'she was over the top there,' 'he is outdoing her.' Yet even persons who have grasped the specific deixis and who know how to linguistically orient themselves in physical space do not necessarily need to see through the social commonplace of spatial circumstances in expressions like 'to be on to someone,' 'to be into something,' or 'to be on about someone.' Only the knowledge about the basic structure of orientation allows him to link their socio-symbolic and socio-cultural adoption in communication practice. 
In German, socio-symbolic markers on a morphological and syntactic level are less perceptible, yet clearly identifiable (Wolfram 1987; Wald 1987). During the discussion on language barriers German sociolinguistics adopted as a starting point the hypothesis of class-specific syntactic rules, which however empirically turned out rather to be rules on mediaspecific syntactic rules opposed to syntax of written language. Similarly, not all syntactic varieties can be explained by media-specific and situational conditions. Their particular sociolectal applications would have to be described in a 'socio-syntactic' model. The same applies for morphological variations of pronoun systems, forms of address, case systems and gender. Reductions in the form content of the temporal and numeric markers are not always explicable in phonetic and dialect-grammatical terms. On a universal level and in intercultural comparison there is an abundance of examples. But it is necessary to distinguish, whether they carry social meaning in the sense of denotative reference to morphologically represented facts or whether they are pragmatic indicators for connotative association of social-deictive hints about the speaker or group of speakers.

Written language is also a social symbol beyond its communicative, codified, and normed function. It is 'the symbol of a culture' (Coulmas 1981: 15), an expression of national, cultural, and sub-cultural identity of social groups, peoples, religious communities, minorities, internetsubcultures of a sometimes considerably critical nature. It is quite rightly a central focus of applied sociolinguistics in fields such as speech planning, speech politics, alphabetization, language didactics, new media, etc. (Stubbs 1980; Glück 1987; Hess-Lüttich 2001; Wende 2002).

Similarly to 'socio-lexis,' 'socio-phonetics' is one of the fields that can more easily benefit from traditional linguistics, which has especially in dialectological studies described a substantial amount of socially relevant features that are open to new interpretation from an explicitly sociolinguistic point of view. Traditional dialect studies have found a methodologically more elaborated and sociologically more sensitive approach, first in the American discipline of 'social dialectology' (see works by Labov; cf. Dittmar 1983b: 29-30) and subsequently also in the Germanspeaking world (Ammon 1978; Besch 1981; Löffler 1994; Mattheier 1980; Barbour and Stevenson 1998). Interpretation of social-symbolic functions of language can be conducted with special precision on a phonetic level, even in cases when it is not expressively accomplished under the label of 'socio-phonetics' (cf. Dressler and Wodak 1982). It is not simply about stylistic-sociolectal selections with the conscious objective of social significance (i.e., the choice of dialect rather than standard language owing to group-oriented psychological reasons, the choice of accent for local em- 
phasis), but also about the involuntary display of social information about the speaker. It is even possible that the speaker thus is faced with social sanctions induced by the fact that his acquired and automatically applied form of phonetic speech realisation marks him as a specific social subject (see dialect as 'speech- and integration-barrier,' Jakob 1992; HessLüttich 2000).

The analysis of stigmatized articulation and intonation, the inventory of allophonic variations with their corresponding sociolectal evaluation, of systematic differentiation between allophonic variants and sociophonetic variables, the socio-stylistic categorisation of articulation levels (from very formal [Bühnenhochlautung] to slang and colloquial speech) - all these are of immeasurable value, also for the applied dimension of the study of language use, language criticism, language teaching, and language education both in terms of first language and foreign language education. The linguistic distinction between, i.e., the examination of sounds as elements of phonemic systems on the one hand, and sounds as carriers of social-symbolic functions on the other, with its language theoretical intention and reference to all levels of language, increases the awareness for what Ralph Fasold emphasized in critical disjointing from common grammatical description in systemic linguistics (or German Grammatikographie - is there such a thing as 'grammarography' in English?): 'the social identity function of language is conceptually separate from the idea-communicating function' (Fasold 1987: 1127).

\section{Language and prestige}

The recent observation of language on the discourse level has obtained a higher effect than studies on the classical levels of linguistic description: 'It is commonly argued that where intelligibility is not in question, language differences serve primarily to mark social identity and are perpetuated in accordance with established norms and traditions' (Gumperz 1994 [1982]: 39). In the 1970s, the primary focus lay on the connection between language and power, i.e., on language and social class (Neuland 1975). However, before long, the focal point shifted to the question of the influence of social surroundings, communities, and networks on everyday language behavior (Romaine 1982; Milroy 1987). Social aspects were further introduced into studies on diglossics and polyglossics. Different studies exemplified the dependence between the respective choice of code or language and the numerous extra-linguistic factors leading to different scales of prestige speech marking (Fasold 1984). 
However, the allocation of prestige in language use is not a new phenomenon. Even in the early period, certain languages in Europe were considered more or less prestigious. With the urbanization and the rise of the bourgeoisie language became increasingly important as a means for social differentiation and esteem. In France, the nobility's style and diction became the role model for the upwards-striving bourgeoisie (Bourdieu 1991: 46). Far into the last century it was imperative to master the prestige-varieties in order to ascend into higher social classes. Even today in Western industrial societies the quality assessment of services strongly depends on linguistic performance (Fairclough and Wodak 1997: 259). But one needs to distinguish between the macro-social and the micro-social developments: 'Whenever networks of relationships reflect long term interpersonal cooperation in the performance of regular tasks and the pursuit of shared goals, they favor the creation of behavioral routines and communicative conventions that become conventionally associated with and serve to mark component activities' (Gumperz 1994 [1982]: 42).

In Western-European culture languages there is a high covariance of prestige and closeness to standard and also of variety and formality of the communicative situation as a 'congruent pattern' of socially competent speakers (Halliday 1978: 156; exception: Switzerland as special case, where high German standard pronunciation is evaluated negatively headword 'media-specific diglossia,' cf. Hess-Lüttich 2000). The 'democratization of discourse' as discussed by Fairclough (1992) and its relativization of asymmetries in linguistic rights is a comparatively recent phenomenon. In England, it has also led to the acceptance of social and regional varieties next to 'Queen's English' and 'Received Pronunciation' in public discourse and the electronic media.

Despite these developments, the asymmetries have not been completely eliminated. Indeed, they are now dialogically manifested in a more subtle way. Commercial conversation training programmes are now aimed at imparting social competence with the objective of interest enforcement. Superiors invite their employees to express criticism and pretend to be open for suggestions while they in actual fact retain control over the conversation. The collegial formulations adopted are not to be misunderstood as being informal and personal, for they might become conversational pitfalls. 'Synthetic personalization' and 'conversation control skills' (Fairclough 1992: 217) are understood as calculated tactics and as the art of making 'conversation control' an inclusive instrument of 'social control.'

In actual fact, one cannot say that such conversational tactics and routines have lead to an actual democratization of institutionally asymmetric 
communicative situations in the sense of discourse that is free of powerenforcement (Habermas 1981). Today as much as ever, public discourse such as in politics, the media, economy, education, and science is not simply about communication, but - horribile dictu - about power. The whole arsenal of the antique ars sermonis was practically dedicated to the objective to convincere: to 'convince the opposite party.' The ambivalent maxim of persuadere always contained both: to 'convince' with the better argument, and to 'persuade' or 'win someone over' with the rhetorically more ingenious strategy. If 'prestige' is linguistically used in order to deceive others about one's objectives, one's competence, and one's status, the expression 'prestige' (from Late Latin praestigium pretence, deception, trickery, illusion) almost returns to its original meaning. Under the influence of personal and social cognition the socio-symbolic function of language in discourse increases equally to the socio-symbolic function of status insignia in society.

Those holding power in discourse determine the nature and duration of a conversation and the distribution of turns. They are able to manipulate the conversational partner, i.e., in proposing political advertising as a dialogue with the public. Further, they are in a position to convey ideologies and representations of the truth (cf. Fairclough and Wodak 1997). Pierre Bourdieu (1991: 166) calls the power of inducing others to adopt one's own construction of the truth the 'symbolic power of language.' In his view, this power is part of categories that are central for the distinction of social difference. At least this is what can be deduced from a number of dispersed hints about language in his monumental work La distiction. Critique sociale du jugement (1979). He maintains that 'le goût est l'opérateur pratique de la transmutation des choses en signes distincts et distinctifs ... il fait accéder les différences inscrites dans l'ordre physique des corps, à l'ordre symbolique des distinctions significantes' (1979: 194); As an example, Bourdieu at this point mentions the unequally distributed '... l'aptitude, très inégalement répartie, à adopter le rapport au langage qui est appelé dans toutes les situations de conversation mondaine' (1979: 194). While the 'bourgeoisie' is in possession of this skill of engaging in distinguished chatter, of elegantly changing the subject, of grammatical correctness and syntactic security, the 'worker' remains with his dialectal Argot, full of stereotypes, situational, elliptical, full of experiential and traditional values and immersed with union phraseology (cf. 1987: 616, 679). 'Le langage populaire' (1979: 537) stands in opposition to public discourse with its 'langage routinisé et routinisant' (1979: 538), creating distance, concealing and euphemizing, neutralizing and abstracting, and which 'permettant de parler sans penser ce qu'on parle' (1979: 538). 
This distinction is just as practical as it is partial with its description of the vivid and colorful language of the workers on the one hand and the dull and barren language of the bourgeoisie on the other. It very much invokes Bernstein's account of the 'restricted codes' of the 'working class' and the 'elaborated codes' of the 'middle class' (Bernstein 1971). But differently to Bernstein who argued that compensatory (language) education would obtain an emancipatory force of comprehending one's own social situation by linguistically bringing it to the point, Bourdieu generally distrusts the Sprache der Herrschenden (the language of those in power), arguing that

le fait que les oppositions semi codifiées que véhicule le langage se retrouvant avec des valeurs très voisines, au principe de la vision dominante du monde social, dans toutes les formations sociales divisées en classes ... se comprend si l'on sait que, réduites à leur structure formelle, les mêmes relations fondamentales, celles qu'expriment précisement les grandes relations d'ordre (haut/bas, fort/faible, etc.), se retrouvant dans toutes les sociétés diversées en classes. (Bourdieu 1979: 548)

Les contradictions ou les paradoxes auxquels conduisent les classements de la pratique ordinaire ne tiennent pas ... à une sorte d'insuffisance essentielle du langage ordinaire, mais au fait que ces actes socio-logiques ne sont pas orientés vers la recherche de la cohérence logique et que, à la différence des usages philologiques, logiques, ou linguistiques di langage, ils obéissent àla logique du parti-pris qui, comme au tribunal, affronte non des jugements logiques, justiciables du seul critère de cohérence, mais des accustions et des défenses. Sans même qu'il soit besoin de rappeler tout ce que recouvre l'opposition, bien oubliée des logiciens et même des linguistes, entre l'art de convaincre et l'art de persuader, comment ne pas voir que l'usage scolaire est à l'usage que l'orateur, l'avocat ou le militant font du langage ce que les systèmes de classement du logicien ou du statisticien soucieux de cohérence et de compatibilité avec les faits sont aux catégorisations et aux catégorèmes de l'existence quotidienne qui, l'étylogie le dit, se situent dans la logique du procès (au sens ordinaire mais aussi au sens de Kafka ...). (Bourdieu 1979: 554-555)

With reference to an earlier study of Bourdieu's (on the Berber society), Hodge and Kress (1991: 70) attempt to linguistically verify these arguments in terminis of Halliday's Social Semiotic. They projected Halliday's structuralistic classification (male/female, interior/exterior, day/night) on to the syntagma of process (verb), agent (subject), patient (object), and circumstances (temporal- and local adverbials) and tried to demonstrate the linguistic manifestation of social order relations:

To take the scheme to its most abstract and general form we would need to take syntagms in terms of power, socially ascribed power, assigned by different para- 
digmatic schemes in different societies, but following common forms in all societies, starting from universal principles of classification in all societies. The essential sytagm of power . . . is in fact a sentence of the form ' $\mathrm{X}$ controls $\mathrm{Y}$ ' ... Syntagms of power require the relevant world to be classified in terms of power: people, places, things, times ... Differences in class or status typically have to describe a continuum of degrees of power, as well as separating off separate groups. (Hodge and Kress 1991: 72)

However: 'There may also be some degree of social mobility to challenge the neatness of the classification scheme derived from this principle. Every classification scheme is tidier than the reality it classifies' (Hodge and Kress 1991: 73).

\section{References}

Adamzik, Kirsten (ed.) (2000). Textsorten. Analysen und Reflexionen, Tübingen: Stauffenburg.

Ammon, Ulrich (1978). Schulschwierigkeiten von Dialektsprechern. Weinheim/Basel: Beltz. Andresen, Helga et al. (eds.) (1978). Sprache und Geschlecht, 3 vols. Osnabrück: Obst.

Androutsopoulos, Jannis (1998). Deutsche Jugendsprache. Untersuchungen zu ihren Strukturen und Funktionen. Frankfurt/Berlin/Bern: Lang.

Barbour, Stephen and Stevenson, Patrick (1998). Variation im Deutschen. Soziolinguistische Perspektiven. Berlin/New York: Walter de Gruyter.

Bausinger, Hermann (1984). Deutsch für Deutsche, Dialekte, Sprachbarrieren, Sondersprachen, Frankfurt: Fischer.

Bergmann, Günther (1987). Paralinguale Phänomene. In Sociolinguistics / Soziolinguistik. An International Handbook of the Science of Language and Society / Ein Internationales Handbuch zur Wissenschaft von Sprache und Gesellschaft, U. Ammon, N. Dittmar, and K. J. Mattheier (eds.), 1216-1227. Berlin/New York: Walter de Gruyter.

Bernsdorf, Wilhelm (ed.) (1972). Wörterbuch der Soziologie, 3 vols. Frankfurt: Fischer.

Bernstein, Basil (1971). Class, Codes, and Control, 2 vols. London: Routledge and Kegan Paul.

Berruto, Gaetano (1987). Varietät. In Sociolinguistics / Soziolinguistik. An International Handbook of the Science of Language and Society / Ein Internationales Handbuch zur Wissenschaft von Sprache und Gesellschaft, U. Ammon, N. Dittmar, and K. J. Mattheier (eds.), 263-267. Berlin/New York: Walter de Gruyter.

Besch, Werner et al. (1981). Sprachverhalten in ländlichen Gemeinden, 2 vols. Berlin: Erich Schmidt.

Bourdieu, Pierre (1979). La distiction. Critique sociale du jugement. Paris: Minuit.

Bourdieu, Pierre (1991). Language and Symbolic Power. Cambridge: Harvard University Press.

Bredehöft, Sonja and Singermann, Markus (1989). Analyse zur Studentensprache des frühen 19. Jahrhunderts. Osnabrücker Beiträge zur Sprachtheorie 41, 97-122.

Bühler, Karl (1982 [1934]). Sprachtheorie. Stuttgart: Fischer.

Burger, Harald et al. (1982). Handbuch der Phraseologie. Berlin/New York: Walter de Gruyter. 
Chesebro, James W. (1981). Gay Speak: Gay Male and Lesbian Communication. New York: Pilgrim Press.

Claessens, Dieter (1995 [1965]). Status als entwicklungspsychologischer Begriff. Hamburg: Kovac.

Claessens, Dieter (1977). Gruppen und Gruppenverbände. Darmstadt: Wiss. Buchges.

Cölfen, Hermann et al. (eds.) (1999). Sprache in religiösen Kontexten. Oldenburg: Obst.

Coulmas, Florian (1981). Routine im Gespräch. Wiesbaden: Athenaion.

Crystal, David (1987). Cambridge Encyclopedia of Language. Cambridge: Cambridge University Press.

Dittmar, Norbert (1983a). Descriptive and explanatory power of rules in sociolinguistics. In The Sociogenesis of Language and Human Conduct, Bruce Bain (ed.), 225-255. New York/London: Kluwer.

Dittmar, Norbert (1983b). Soziolinguistik - Teil 2: Soziolinguistik in der Bundesrepublik Deutschland. Studium Linguistik 14, 20-57.

Dittmar, Norbert and Klein, Wolfgang (1975). Heidelberger Forschungsprojekt PidginDeutsch.' Sprache und Kommunikation ausländischer Arbeiter. Kronberg: Scriptor.

Dressler, WoIfgang and Wodak, Ruth (1982). Socio-phonological methods in the study of sociolinguistic Variation in Viennese German. Language in Society 11, 339-370.

Ehlich, Konrad (1986). Xenismen und die bleibende Fremdheit des Fremdsprachensprechers. In Integration und Identität, E. W. B. Hess-Lüttich (ed.), 43-54. Tübingen: Gunter Narr.

Elias, Norbert (1977). Über den Prozeß der Zivilisation, 2 vols. Frankfurt: Suhrkamp.

Fairclough, Norman (1992). Discourse and Social Change. Cambridge: Polity Press.

Fairclough, Norman and Wodak, Ruth (1997). Critical discourse analysis. In Discourse as Social Interaction, Teun van Dijk (ed.), 258-284. London: Sage.

Fasold, Ralph W. (1984). The Sociolinguistics of Society. Oxford: Blackwell.

Fasold, Ralph W. (1987). Phonetics / phonology. In Sociolinguistics / Soziolinguistik. An International Handbook of the Science of Language and Society / Ein Internationales Handbuch zur Wissenschaft von Sprache und Gesellschaft, U. Ammon, N. Dittmar, and K. J. Mattheier (eds.), 1126-1134. Berlin/New York: Walter de Gruyter.

Fichte, Hubert (1972). Interviews aus dem Palais d'Amour. Reinbek: Rowohlt.

Fisch, Rudolf (1987). Gruppe. In Sociolinguistics / Soziolinguistik. An International Handbook of the Science of Language and Society / Ein Internationales Handbuch zur Wissenschaft von Sprache und Gesellschaft, U. Ammon, N. Dittmar, and K. J. Mattheier (eds.), 150-157. Berlin/New York: Walter de Gruyter.

Giles, Howard, Hewstone, Miles, Ryan, Ellen B., and Johnson, Patricia (1987a). Research of language attitudes. In Sociolinguistics / Soziolinguistik. An International Handbook of the Science of Language and Society / Ein Internationales Handbuch zur Wissenschaft von Sprache und Gesellschaft, U. Ammon, N. Dittmar, and K. J. Mattheier (eds.), 585-597. Berlin/New York: Walter de Gruyter.

Giles, Howard, Hewstone, Miles, Ryan, Ellen B., and Johnson, Patricia (1987b). The measurement of language attitudes. In Sociolinguistics / Soziolinguistik. An International Handbook of the Science of Language and Society / Ein Internationales Handbuch zur Wissenschaft von Sprache und Gesellschaft, U. Ammon, N. Dittmar, and K. J. Mattheier (eds.), 1068-1081. Berlin/New York: Walter de Gruyter.

Glück, Hartmut (1987). Schrift und Schriftlichkeit. Eine sprach- und kulturwissenschaftliche Studie, Stuttgart: Metzler.

Götze, Lutz and Hess-Lüttich, Ernest W. B. (2002). Grammatik der deutschen Sprache. Sprachsystem und Sprachgebrauch, 4th ed. Gütersloh: Bertelsmann.

Gumperz, John J. (1994 [1982]). Discourse Strategies. Cambridge: Cambridge University Press. 
Habermas, Jürgen (1981). Theorie des kommunikativen Handelns, 2 vols. Frankfurt am Main: Suhrkamp.

Hall, Kira (ed.) (1997). Queerly Phrased: Language, Gender, and Sexuality. Oxford/New York: Oxford University Press.

Halliday, Michael A. K. (1978). Language as Social Semiotic: The Social Interpretation of Language and Meaning. London: Arnold.

Hanke, Michael (2000). Skeptizistische Traditionen in Theorien der Kommunikation. Kodikas/Code 23 (1-2), 69-83.

Hartig, Matthias (1985). Soziolinguistik. Bern: Lang.

Henne, Helmut (1986). Jugend und ihre Sprache. Berlin/New York: Walter de Gruyter.

Henne, Helmut and Objartel, Georg (eds.) (1984). Bibliothek zur historischen deutschen Studenten- und Schülersprache, 6 vols. Berlin/New York: Walter de Gruyter.

Hess-Lüttich, Ernest W. B. (1981). Grundlagen der Dialoglinguistik (= Soziale Interaktion und literarischerDialog 1). Berlin: Erich Schmidt.

Hess-Lüttich, Ernest W. B. (1984). Kommunikation als ästhetisches Problem. Tübingen: Gunter Narr.

Hess-Lüttich, Ernest W. B. (1985). Zeichen und Schichten in Drama und Theater (= Soziale Interaktion und literarischer Dialog 2). Berlin: Erich Schmidt.

Hess-Lüttich, Ernest W. B. (1987). Angewandte Sprachsoziologie. Stuttgart: Metzler.

Hess-Lüttich, Ernest W. B. (2000). Sonderweg der Dialekte? Eine sprachkritische Polemik pro Helvetia Europaea. In Sprachsplitter und Sprachspiele: Nachdenken über Sprache und Sprachgebrauch, Jürg Niederhauser and Stanislaw Szlek (eds.), 185-206. Bern: Lang.

Hess-Lüttich, Ernest W. B. (ed.) (1982). Multimedial Communication, 2 vols. Tübingen: Gunter Narr.

Hess-Lüttich, Ernest W. B. (ed.) (1986). Integration und Identität. Tübingen: Gunter Narr.

Hess-Lüttich, Ernest W. B. (ed.) (1992). Medienkultur - Kulturkonflikt. Opladen: Westdeutscher Verlag.

Hess-Lüttich, Ernest W. B. (ed.) (2001). Medien, Texte und Maschinen. Angewandte Mediensemiotik. Wiesbaden: Westdeutscher Verlag.

Hodge, Robert and Kress, Gunther (1991). Social Semiotics. Ithaca, NY: Cornell University Press.

Hufschmidt, Jochen et al. (1983). Sprachverhalten in ländlichen Gemeinden. Dialekt und Standardsprache im Sprecherurteil. Berlin: Erich Schmidt.

Jacobs, Greg (1996). Lesbian and gay male language use: A critical review of the literature. American Speech 71 (1), 49-71.

Jäger, Siegfried et al. (1978). Schichtenspezifischer Sprachgebrauch von Schülern, 3 vols., Kronberg: Scriptor.

Jakob, Karlheinz (1992). Prestige und Stigma deutscher Dialektlandschaften. Zeitschrift für Dialektologie und Linguistik 59 (2), 167-182.

Klann-Delius, Gisela (1987). Sex and language. In Sociolinguistics / Soziolinguistik. An International Handbook of the Science of Language and Society / Ein Internationales Handbuch zur Wissenschaft von Sprache und Gesellschaft, U. Ammon, N. Dittmar, and K. J. Mattheier (eds.), 767-780. Berlin/New York: Walter de Gruyter.

Klein, Wolfgang (1974). Variation in der Sprache. Ein Verfahren zu ihrer Beschreibung. Kronberg: Scriptor.

Klein, Wolfgang (1987). Varietätengrammatik. In Sociolinguistics / Soziolinguistik. An International Handbook of the Science of Language and Society / Ein Internationales Handbuch zur Wissenschaft von Sprache und Gesellschaft, U. Ammon, N. Dittmar, and K. J. Mattheier (eds.), 997-1006. Berlin/New York: Walter de Gruyter. 
Klein, WoIfgang and Dittmar, Norbert (1979). Developing Grammars. The Acquisition of German by Foreign Workers. Heidelberg/New York: Springer.

Krause, Wolf-Dieter (ed.) (2000). Textsorten. Kommunikationslinguistische und konfrontative Aspekte. Frankfurt: Lang.

Küpper, Heinz (1978). ABC-Komiker bis Zwitschergemüse. Das Bundessoldatendeutsch. Wiesbaden: Verlag für deutsche Sprache.

Küpper, Heinz and Küpper, Marianne (1972). Schülerdeutsch. Ein Schlüssel zum Sprachschatz der jungen Generation. Düsseldorf: Claassen.

Labov, William (1971). Variation in language. In The Learning of Language, Carroll E. Reed (ed.), 187-221. New York: Appleton-Century-Crofts.

Labov, William (1972). Language in the Inner City. Philadelphia: University of Pennsylvania Press.

Labov, William (1980). Sprache im sozialen Kontext. Königstein: Athenäum.

Leap, William L. (1996). Word's Out: Gay Men's English. Minneapolis: University of Minnesota Press.

Löffler, Heinrich (1994). Germanistische Soziolinguistik, vol. 2. Berlin. Erich Schmidt.

Lüger, Heinz-Helmut (ed.) (2001). Höflichkeitsstile. Frankfurt/Berlin/Bern: Lang.

Mattheier, Klaus (1980). Pragmatik und Soziologie der Dialekte. Einführung in die kommunikative Dialektologie des Deutschen. Heidelberg: Quelle and Meyer.

Milroy, Leslie (1987). Language and Social Networks, 2nd ed. Oxford: Blackwell.

Möhn, Dieter (1980). Sondersprachen. In Lexikon der germanistischen Linguistik, vol. 1, 384-390. Tübingen: Niemeyer.

Neuland, Eva (1975). Sprachbarrieren oder Klassensprache? Frankfurt: Fischer.

Neuland, Eva (ed.) (2002). Jugendsprachen - Spiegel der Zeit. Frankfurt: Lang.

Nöth, Winfried (1994). Der Text als Raum. In Sprache, Onomatopöie, Rhetorik, Namen, Idiomatik, Grammatik. Festschrift für Karl Sornig, Dieter W. Halwachs et al. (eds.), 163-174. Graz: Universität Graz.

Nöth, Winfried (2000). Handbuch der Semiotik. Stuttgart/Weimar: Metzler.

Oksaar, Els (1977). Spracherwerb im Vorschulalter. Einführung in die Pädolinguistik. Stuttgart: Kohlhammer.

Oksaar, Els (1988). Fachsprachliche Dimensionen. Tübingen: Gunter Narr.

Poplack, Shana and Sankoff, David (1987). Code-switching. In Sociolinguistics / Soziolinguistik. An International Handbook of the Science of Language and Society / Ein Internationales Handbuch zur Wissenschaft von Sprache und Gesellschaft, U. Ammon, N. Dittmar, and K. J. Mattheier (eds.), 1174-1180. Berlin/New York: Walter de Gruyter.

Puchner, Guenther (1976). Kundenschall. Das Gekasper der Kirschpflücker im Winter. Munich: Piper.

Pusch, Luise F. (1990). Alle Menschen werden Schwestern. Feministische Sprachkritik. Frankfurt: Suhrkamp.

Richter, Helmut and Weidmann, Fred (1975). Semantisch bedingte Kommunikationskonflikte bei Gleichsprachigen. Hamburg: Buske.

Ris, Roland (1977). Nameneinschätzung und Namenwirklichkeit. Ein Beitrag zur empirischen Sozioonomastik. Onoma 21, 557-576.

Ris, Roland (1995). Populäres Stadtberndeutsch im neuen 'Bernischen Mundartwörterbuch.' In Schweizerdeutsches Wörterbuch, 10-32. Zurich: Huber.

Romaine, Suzanne (1982). Sociolinguistic Variation in Speech Communities. London: Arnold.

Romaine, Suzanne (1984). The Language of Children and Adolescents. Oxford: Blackwell.

Samel, Ingrid (1995). Einführung in die Feministische Sprachwissenschaft. Berlin: Erich Schmidt. 
Scherer, Klaus R. and Giles, Howard (eds.) (1979). Social Markers in Speech. Cambridge: Cambridge University Press.

Schneider, Peter (1974). Die Sprache des Sports. Terminologie und Präsentation in Massenmedien. Eine statistisch-vergleichende Analyse. Düsseldorf: Schwann.

Shin, Kwang Sook (1980). Schichtenspezifische Faktoren der Vornamengebung. Bern: Lang.

Smith, Philip M. (1985). Language, the Sexes and Society. Oxford: Blackwell.

Sornig, Karl (1981). Soziosemantik auf der Wortebene. Stilistische Index-Leistung lexikalischer Elemente an Beispielen aus der Umgangssprache von Graz. Tübingen: Niemeyer.

Steinig, Wolfgang (1976). Soziolekt und soziale Rolle. Düsseldorf: Schwann.

Stubbs, Michael (1980). Language and Literacy: The Sociolinguistics of Reading and Writing. London: Routledge and Kegan Paul.

Tannen, Deborah (1997). Andere Worte, andere Welten: Kommunikation zwischen Frauen und Männern. Frankfurt: Campus.

Trömel-Plötz, Senta (1982). Frauensprache: Sprache der Veränderung. Frankfurt: Fischer.

Wald, Benji (1987). Syntax/Discourse semantics. In Sociolinguistics / Soziolinguistik. An International Handbook of the Science of Language and Society / Ein Internationales Handbuch zur Wissenschaft von Sprache und Gesellschaft, U. Ammon, N. Dittmar, and K. J. Mattheier (eds.), 1164-1174. Berlin/New York: Walter de Gruyter.

Wallbott, Harald G. (1987). Nonverbale phänomene. In Sociolinguistics / Soziolinguistik. An International Handbook of the Science of Language and Society / Ein Internationales Handbuch zur Wissenschaft von Sprache und Gesellschaft, U. Ammon, N. Dittmar, and K. J. Mattheier (eds.), 1227-1237. Berlin/New York: Walter de Gruyter.

Walther, Hans (1972). Soziolinguistisch-pragmatische Aspekte der Namengebung und des Namengebrauchs. Namenkundliche Informationen 20, 49-60.

Wardhaugh, Ronald (1986). An Introduction to Social Linguistics. Oxford: Blackwell.

Watts, Richard, Ide, Sachiko, and Ehlich, Konrad (eds.) (1992). Politeness in Language: Studies in its History, Theory and Practice. Berlin/New York: Mouton de Gruyter.

Weber, Heinz (1980). Studentensprache. Über den Zusammenhang von Sprache und Leben. Weinheim/Basel: Beltz.

Wende, Wara (ed.) (2002). Über den Umgang mit Schrift. Würzburg: Königshausen and Neumann.

Wolfgang, Aaron (ed.) (1984). Nonverbal Behavior: Perspectives, Applications, Intercultural Insights. Lewiston, NY/Toronto: Hogrefe.

Wolfram, Walter A. (1987). Morphology. In Sociolinguistics / Soziolinguistik. An International Handbook of the Science of Language and Society / Ein Internationales Handbuch zur Wissenschaft von Sprache und Gesellschaft, U. Ammon, N. Dittmar, and K. J. Mattheier (eds.), 1144-1153. Berlin/New York: Walter de Gruyter.

Ernest W. B. Hess-Lüttich (b. 1949) is a Full Professor at the University of Berne 〈hess@ germ.unibe.ch $\rangle$. His research interests include dialogue and discourse analysis. His publications include Literary Theory and Media Practice (2000); Wo steht das Kanzleramt? Der Spreebogen (with D. Genske, 2004); Grammatik der deutschen Sprache (with L. Götze, 2006); Nordhausen - eine Spurensuche (with D. Genske, 2007). 